\title{
ペースト法によるTi及びTi合金のホゥ化処理
}

\author{
淽谷佳男*，磯部賢二*，佐藤憲治*，若林 太*
}

\section{Boriding of Unalloyed Titanium and Its Alloy by Paste Method}

Yoshio SHIBUYA*, Kenji ISOBE*, Kenji SATOH* and Futori WAKABAYASHI*

\begin{abstract}
Paste-boriding of titanium and $\mathrm{Ti}-6 \mathrm{Al}-4 \mathrm{~V}$ alloy was carried out in the air by using mixtures made up of $\mathrm{B}_{4} \mathrm{C}$ and $\mathrm{Na}_{2} \mathrm{~B}_{4} \mathrm{O}_{7}$ as the main constituents, $\mathrm{NaBF}_{4}, \mathrm{NH} \mathrm{Cl}_{4}$ and $\mathrm{NaCl}$ as the activators and $\mathrm{Ca}(\mathrm{OH})_{2}$ as binder. The influence of paste compositions on boride formation, and the structure, hardness and wear behavior of the boride layers formed onto the metals were investigated. The results obtained are summarized as follows : The most suitable composition of boriding paste for titanium was $65 \% \mathrm{~B}_{4} \mathrm{C}, 20 \% \mathrm{Na}_{2} \mathrm{~B}_{4} \mathrm{O}_{7}, 8.5 \% \mathrm{NaBF}_{4}, 2.5 \%\left(\mathrm{NH} \mathrm{H}_{4} \mathrm{Cl}+\mathrm{NaCl}\right)$ and $4 \% \mathrm{Ca}(\mathrm{OH})_{2}$, and that for Ti- $6 \mathrm{Al}-4 \mathrm{~V}$ was $75 \% \mathrm{~B} 4 \mathrm{C}$ and $10 \% \mathrm{Na}_{2} \mathrm{~B}_{4} \mathrm{O}_{7}$, with the other materials in the same proportions as for titanium. Two phases of titanium boride were formed $\mathrm{TiB}_{2}$ on the surface and $\mathrm{TiB}$ inside. The $\mathrm{TiB}_{2}$ surface had a hardness of $\mathrm{H}_{K}(0.196 \mathrm{~N}) \quad 3200-4500$. Under identical conditions of formation, the boride layer formed on the titanium was slightly thicker than that on the Ti- $6 \mathrm{Al}-4 \mathrm{~V}$ alloy, but when the surface roughness of after boriding is taken into account, the Ti- $6 \mathrm{Al}-4 \mathrm{~V}$ alloy is superior to the titanium as a candidate for boriding. The wear behavior of paste-borided titanium and Ti- $6 \mathrm{Al}-4 \mathrm{~V}$ alloy was greatly improved over that of untreated specimens.
\end{abstract}

Key Words : Boriding, Titanium, Titanium Alloy

\section{1.緒言}

チタン(Ti)及びTi- 6 Al- 4 V 合金(以下Ti合金と記す) は高強度, 低比重, 耐食性等, 優れた性質があるが硬さ は普通鋼程度で耐摩耗性材料とは言えない。一方, $\mathrm{Ti}$ ホウ化物は極めて硬く耐摩耗性材料として優れているほ か, 低電気抵抗率, 低熱膨張率も兼備している。Ti表 面へのTiホウ化物皮膜形成法としてはTiが反応性に富 むため一般的には非晶質ホウ素(B)を主成分とする粉末 パック法で真空中あるいはAr中で行う場合が多( ${ }^{1) \sim 5) 。 ~}$ 他の方法としては同様にB粉末 ${ }^{6)}, \mathrm{B}_{4} \mathrm{C}^{7)}$ を主成分とし て大気中処理, あるいは溶融塩電解法 ${ }^{8)}$, 浸せき法 ${ }^{9}$, CVD法 ${ }^{10)}$ 等が行われている。処理操作の簡便性, 経済 性を考慮すると浸せき法, 粉末パック法が優れている。 しかし前者は塩浴剤の管理が煩雑, 後者はB粉末が高価, 試料にホウ化剂(薬剤)が固着する，等の欠点がある。

本研究は簡便性, 経剤性に優れた大気中ペースト法に より，良好なTiホウ化物を生成させることを目的とし た。すなわち, $\mathrm{B}_{4} \mathrm{C}$ と $\mathrm{Na}_{2} \mathrm{~B}_{4} \mathrm{O}_{7}$ を主成分とする楽剤を 被処理材に塗布した後, $\mathrm{Al}_{2} \mathrm{O}_{3}$ を主成分とする粉末中に 埋没させ，大気中加熱することにより，前記の目的を満 足する結果を得たので報告する。薬剤の主成分として $\mathrm{B}_{4} \mathrm{C}$ ¿ $\mathrm{Na}_{2} \mathrm{~B}_{4} \mathrm{O}_{7}$ を用いる試みは鉄鋼材料では一般的だ が, 大気中でTi及びTi合金をぺースト法によりホウ化

* 静岡県機械技術指導所（干435 静岡県浜松市小池町2444） The Mechanical Res. Inst. of Shizuoka Pref. (2444, Koikecho, Hamamatsu-shi, Shizuoka 435)
（以下ペーストホウ化と記す）した報告はないようであ る。本研究ではTiホウ化物生成に及ぼす薬剤の影響, 生成したホウ化物の組成, 厚さ, 硬さ等について調べた 結果を示す。

\section{2. 実験方法}

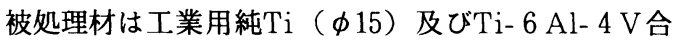
金（ $\phi 13 ）$ を厚さ $2.5 \mathrm{~mm}$ に切り, \#800エメリーペーパー 研磨 $\rightarrow$ 前処理 $\rightarrow$ 薬剂塗布 $\rightarrow$ 乾燥の後ホウ素 (B) の拡散 浸透を行った。前処理はアセトン超音波洗浄 $\rightarrow 3 \% \mathrm{HF}$ $10 \% \mathrm{HNO}_{3}-\mathrm{H}_{2} \mathrm{O}$ 溶液で 10 腐食 $\rightarrow$ 水洗 $\rightarrow$ アトン脱脂 $\rightarrow$ 乾燥の順序で行った。薬剂は $\mathrm{B}_{4} \mathrm{C}, \mathrm{Na}_{2} \mathrm{~B}_{4} \mathrm{O}_{7}, \mathrm{NaBF}_{4}$, $\mathrm{NaCl}, \mathrm{NH}_{4} \mathrm{Cl}$ 及びCa(OH) ${ }_{2}$ の混合物であり, $\mathrm{B}_{4} \mathrm{C}$ は $1173 \mathrm{~K}$ で7.2ks空焼き, $\mathrm{Na}_{2} \mathrm{~B}_{4} \mathrm{O}_{7}$ は1193Kで溶融脱水し た後, 粉末にして用いた。薬剂をエチルアルコールでペー スト状にして, 被処理材表面に $3 \mathrm{~mm}$ 厚さに被覆, 373

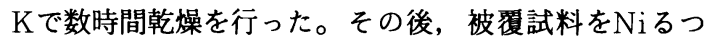
ぼ内の粉末 $\left(2 \% \mathrm{~B}_{4} \mathrm{C}\right.$ 含有 $\left.\mathrm{Al}_{2} \mathrm{O}_{3}\right)$ 中に埋没させ，任意 の温度, 時間で大気中ホゥ化した後, 炉冷を行った。処 理温度は1123〜1283K, 処理時間は14.4〜64.8ksの範囲 である。ホウ化機構を検討するために生成自由エネルギー 変化 $\Delta G_{\mathrm{T}}$ の算出 ${ }^{11)}$ を行った。なお $\Delta H_{298}, S_{298}, C_{\mathrm{P}}$ の値 は化学熱力学表 ${ }^{12) ~ 14) ~}$ より引用した。耐摩耗性の評価は, 潤滑下におけるpin-on-disk型摩耗試験でのホウ化材と 未処理材との摩耗減量及び摩擦係数を比較することによ り行った。pin ( $\phi 7)$ に試料, disk (回転半径 $40 \mathrm{~mm}$ ) にはS $45 \mathrm{C}\left(\mathrm{H}_{\mathrm{R}} \mathrm{C} 51\right)$ を用いた。摩擦時間は3.6ksであり, 
Table 1 X-ray diffraction results observed from surface of titanium and Ti- $6 \mathrm{Al}-4 \mathrm{~V}$ alloy borided at various conditions.
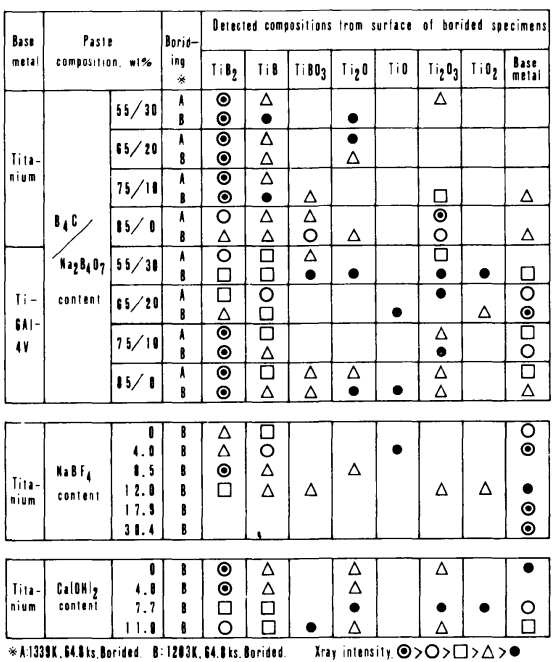

未処理材については摩耗が激しいために，0.3ksとした。

\section{3．実験結果及び考察}

\section{3. $1 \mathrm{Ti}$ ホウ化物生成に及ぼす薬郕の影靇}

3. 1. $1 \mathrm{~B}_{4} \mathrm{C} / \mathrm{Na}_{2} \mathrm{~B}_{4} \mathrm{O}_{7}$ 比の影響

ペースト中の $\mathrm{B}_{4} \mathrm{C}$ と $\mathrm{Na}_{2} \mathrm{~B}_{4} \mathrm{O}_{7}$ の量の合計がペースト 全体の $85 \mathrm{wt} \%$ になるように配合して，最適配合比を検 討した。他の薬剤はすべて同じであり， $8.5 \mathrm{wt} \%$ $\mathrm{NaBF}_{4}, 1.3 \mathrm{wt} \% \mathrm{NaCl}, 1.2 \mathrm{wt} \% \mathrm{NH}_{4} \mathrm{Cl}, 4.0 \mathrm{wt} \%$ $\mathrm{Ca}(\mathrm{OH})_{2}$ をそれぞれ混合させた。表 1 は種々の条件で ホウ化処理したTi及びTi合金表面のX線回折結果であ る。ペースト法による大気中処理により, $\mathrm{B}_{4} \mathrm{C} / \mathrm{Na}_{2} \mathrm{~B}_{4} \mathrm{O}_{7}$ が55/30〜85/ 0 wt\%のすべての範囲でホウ化物が生成 した。しかし，Ti系酸化物もわずかに認められる。ま たすべての処理条件で1339K (A) と1203K (B)とでは検 出された生成物に明確な差は認められない。本法による $\mathrm{Ti}$ の処理では $\mathrm{B}_{4} \mathrm{C} / \mathrm{Na}_{2} \mathrm{~B}_{4} \mathrm{O}_{7}$ 量が $65 / 20 \mathrm{wt} \%$ で $1203 \mathrm{~K}$ 処 理の場合，表面は $\mathrm{TiB}_{2}$ が主体に生成し，最適な処理条 件であった。一方， $\mathrm{Na}_{2} \mathrm{~B}_{4} \mathrm{O}_{7}$ を含まない場合は，ホウ 化物よりあ酸化物が主体に生成して不適当である。Ti 合金ではTiの場合と異なり $\mathrm{Na}_{2} \mathrm{~B}_{4} \mathrm{O}_{7}$ を含まない，ある いは含有量が少ない75/10wt\%の場合，1203K処理で良 好な結果が得られた。

酸化物生成における $\Delta G_{1203 K}$ の比較では(1)，(2)式のよ うに $\mathrm{Al}_{2} \mathrm{O}_{3}$ の值は $\mathrm{TiO}_{2}$ (後述), $\mathrm{VO}$ のそれらに比べょ り負であった。従ってTi合金はX線回折図からは確認さ れていないが, ペーストホウ化の過程で表面に安定な $\mathrm{Al}_{2} \mathrm{O}_{3}$ が生成して, Bあるいは $\mathrm{O}_{2}$ の内部への拡散を抑制 していることが考えられる。またTi合金では $\mathrm{Na}_{2} \mathrm{~B}_{4} \mathrm{O}_{7}$ の存在は表面の $\mathrm{Al}$ あるいはV 酸化物と反応してホウ化
を抑制したことが推察される。一方，Tiの場合は逆に 適量の $\mathrm{Na}_{2} \mathrm{~B}_{4} \mathrm{O}_{7}$ を含む場合が良好であった。これはTi 表面の生成物 $\mathrm{TiO}_{2}$ は $\mathrm{Al}_{2} \mathrm{O}_{3}$ ほど安定ではなく反応が生 じやすいが，ガラス質の $\mathrm{Na}_{2} \mathrm{~B}_{4} \mathrm{O}_{7}$ の存在は，外部から の $\mathrm{O}_{2}$ の侵入を抑制してホウ化を促進させたことが考え られる。しかしこれらは明確ではなく今後検討を要する。 またTi合金ではすべての処理条件で素地が検出された がこれはTiの場合に比べ生成したホゥ化物皮膜厚さが 薄いことに起因している。

\section{1. $2 \mathrm{NaBF}_{4}$ の影響}

鉄鋼の浸砽ではフッ化ホウ素酸塩の添加は良好であ る ${ }^{15)}$ 之言われている。ペーストホゥ化したTi表面の生成 物に及ぼす薬剤中の $\mathrm{NaBF}_{4}$ 量（（ 0 ～ $\left.30.4 \mathrm{wt} \%\right)$ の影響 を検討した（表 1 ）。 $\mathrm{NaBF}_{4}$ が零でもホウ化物は生成す るがX線回折ピーク強度は低い。8.5wt％含有させた場 合良好なホウ化物が得られ，12wt\%以上では表面部が 脆化して，17.9及び $30.4 \mathrm{wt} \%$ でははく離した。すなわち $8.5 \mathrm{wt} \%$ 含有の場合が最適であった。 $\mathrm{NaBF}_{4}$ は熱力学 的データが少ないため，その挙動は明確ではないが，高 温において(3)式のように $\mathrm{NaF}$ と $\mathrm{BF}_{3}$ に解離する ${ }^{16)}$ と考え られる。次に生成した $\mathrm{BF}_{3}$ と $\mathrm{Ti}$ が反応して直接ホウ化 物が生成する(4) (6)式の反応は $\Delta G>0$ であることより 生じにくい。一方， $\mathrm{NaBF}_{4}$ 在添加することによりホウ 化が促進した事実より生成した $\mathrm{NaF}, \mathrm{BF}_{3}$ は促進剤の 役目をしていると言える。

\section{$\Delta G_{1203 K}(\mathrm{~kJ} / \mathrm{mol})$}

$$
\begin{array}{lr}
2 \mathrm{Al}+3 / 2 \mathrm{O}_{2} \rightarrow \mathrm{Al}_{2} \mathrm{O}_{3} & -1297 \cdots(1) \\
2 \mathrm{~V}+\mathrm{O}_{2} \rightarrow 2 \mathrm{VO} & -640 \cdots(2) \\
\mathrm{NaBF}_{4}=\mathrm{NaF}+\mathrm{BF}_{3} & -\cdots(3) \\
2 \mathrm{BF}_{3}+\mathrm{Ti} \rightarrow \mathrm{TiB}_{2}+3 \mathrm{~F}_{2} & +1824 \cdots(4) \\
2 \mathrm{BF}_{3}+2 \mathrm{Ti} \rightarrow 2 \mathrm{TiB}+3 \mathrm{~F}_{2} & +1809 \cdots(5) \\
2 \mathrm{BF}_{3}+2 \mathrm{TiB} \rightarrow 2 \mathrm{TiB}_{2}+3 \mathrm{~F}_{2} & +2984 \cdots(6)
\end{array}
$$

\section{1. $3 \mathrm{Ca}(\mathrm{OH})_{2}$ の影響}

ペーストホウ化したTi表面の生成物に及ぼす薬剤中 の $\mathrm{Ca}(\mathrm{OH})_{2}$ 量 $(0 \sim 11.0 \mathrm{wt} \%)$ の影響を検討した。 $\mathrm{Ca}(\mathrm{OH})_{2}$ を添加する目的は試料に被覆した薬剤が脱落 しないよう粘結性を付与するためである。表 1 に示すよ うにCa $(\mathrm{OH})_{2}$ 量が11.0wt\%以内では，すべてホウ化物 が生成した。 $\mathrm{Ca}(\mathrm{OH})_{2}$ が零の場合, 薬剤が脱落しやす い欠点があり，7.7及び $11.0 \mathrm{wt} \%$ では薬剤が試料に保持 され良好であった。しかしその場合，生成した $\mathrm{TiB}_{2}$ の (101)ピーク強度は $4.0 \mathrm{wt} \%$ の場合のそれに比べ約 $1 / 3$ で あった。したがって $\mathrm{Ca}(\mathrm{OH})_{2}$ 量は $4.0 \mathrm{wt} \%$ の添加が最 適である。

\section{2 ホウ化機構}

薬剤として $\mathrm{B}_{4} \mathrm{C}$ とアルカリ金属炭酸塩の混合を用いた 鉄鋼材料のホウ化機構については種々の報告 ${ }^{16) \sim 18)}$ がある。 本法の反応も主反応はそれらと類似であると推察するが， 
生成自由エネルギー変化 $\Delta G$ より Tiのホウ化機構を検討 する。次式は種々の反応における $\Delta G_{1203 K}$ である。 $\mathrm{B}_{4} \mathrm{C}$ が主成分の場合, 高温において $\mathrm{B}_{4} \mathrm{C}$ と $\mathrm{O}_{2}$ が反応して直 接Bが生成する反応（(7) (9)式）よりす, $\mathrm{B}_{2} \mathrm{O}_{3}$ が生成 する反応（(10)～(12)式）が優先すると考えられる。また生 成した $\mathrm{B}_{2} \mathrm{O}_{3}$ は $\mathrm{Ti}, \mathrm{TiO} 反$ 応してホウ化物が直接生成 する（(13)，(14)式）ことは考えにくく，Tiで還元され ((15) (17)式), 生成したBがTi中に拡散してホウ化物が生 成する（(18)～(21)式）, と考えた方が妥当である。なお, (10) (12)式の $\Delta G$ は $1273 \mathrm{~K}^{17)}$ における值である。一方, 薬 剤として $\mathrm{B}_{4} \mathrm{C}$ と $\mathrm{Na}_{2} \mathrm{~B}_{4} \mathrm{O}_{7}$ を用いる場合, 一般に(22) 式の 反応が生じる ${ }^{16)}$ と言われている。この反応は熱力学的に は不可能と考えるが，上記薬剤による鋼のホウ化で, Feホウ化物が生成した多くの報告があることより, 全 反応としては(22)式は生じると考えられる。また薬剤中 の $\mathrm{NH}_{1} \mathrm{Cl}$ は熱解離, 還元・置換反応が生じ16), 生成し た $\mathrm{BCl}_{3}$ 及び $\mathrm{H}_{2}$ と $\mathrm{Ti}$ との反応により表面にB及び $\mathrm{TiB}_{2}$ が 析出していることが予想され, ホゥ化に寄与していると 考えられる。すなわち，これらの反応が平行あるいは複 合してホウ化は進行すると推察される。

$$
\Delta G_{1203 \mathrm{~K}}(\mathrm{~kJ} / \mathrm{mol})
$$

\begin{tabular}{|c|c|}
\hline $\mathrm{B}_{4} \mathrm{C}+\mathrm{O}_{2} \rightarrow 4 \mathrm{~B}+\mathrm{CO}_{2}$ & $-328 \cdots(7)$ \\
\hline $2 \mathrm{~B}_{4} \mathrm{C}+\mathrm{O}_{2} \rightarrow 8 \mathrm{~B}+2 \mathrm{CO}$ & $-298 \cdots(8)$ \\
\hline $\mathrm{B}_{4} \mathrm{C}+\mathrm{CO}_{2} \rightarrow 4 \mathrm{~B}+2 \mathrm{CO}$ & $+28 \cdots(9)$ \\
\hline $\mathrm{B}_{4} \mathrm{C}+4 \mathrm{O}_{2}=2 \mathrm{~B}_{2} \mathrm{O}_{3}+\mathrm{CO}_{2}$ & $-2358^{17)} \cdots(10)$ \\
\hline $2 \mathrm{~B}_{4} \mathrm{C}+7 \mathrm{O}_{2}=4 \mathrm{~B}_{2} \mathrm{O}_{3}+2 \mathrm{CO}$ & $-2180^{17)} \cdots(11)$ \\
\hline $\mathrm{B}_{4} \mathrm{C}+7 \mathrm{CO}_{2}=2 \mathrm{~B}_{2} \mathrm{O}_{3}+8 \mathrm{CO}$ & $-936^{17)} \cdots(12)$ \\
\hline $2 \mathrm{~B}_{2} \mathrm{O}_{3}+2 \mathrm{Ti} \rightarrow 2 \mathrm{TiB}_{2}+3 \mathrm{O}_{2}$ & $+1313 \cdots(13)$ \\
\hline $\mathrm{B}_{2} \mathrm{O}_{3}+\mathrm{TiO} \rightarrow \mathrm{TiB}_{2}+2 \mathrm{O}_{2}$ & $+2675 \cdots(14)$ \\
\hline $2 / 3 \mathrm{~B}_{2} \mathrm{O}_{3}+2 \mathrm{Ti} \rightarrow 4 / 3 \mathrm{~B}+2 \mathrm{TiO}$ & $-206 \cdots(15)$ \\
\hline $2 \mathrm{~B}_{2} \mathrm{O}_{3}+3 \mathrm{Ti} \rightarrow 4 \mathrm{~B}+3 \mathrm{TiO}_{2}$ & $-167 \cdots(16)$ \\
\hline $\mathrm{B}_{2} \mathrm{O}_{3}+2 \mathrm{Ti} \rightarrow 2 \mathrm{~B}+\mathrm{Ti}_{2} \mathrm{O}_{3}$ & $-207 \cdots(17)$ \\
\hline $\mathrm{Ti}+2 \mathrm{~B} \rightarrow \mathrm{TiB}_{2}$ & $-308 \cdots(18)$ \\
\hline $\mathrm{Ti}+\mathrm{B} \rightarrow \mathrm{TiB}$ & $-159 \cdots(19)$ \\
\hline $\mathrm{TiB}+\mathrm{B} \rightarrow \mathrm{TiB}_{2}$ & $-149 \cdots(20)$ \\
\hline $\mathrm{TiB}_{2}+\mathrm{Ti} \rightarrow 2 \mathrm{TiB}$ & $-9.7 \quad \cdots(21)$ \\
\hline $6 \mathrm{~B}_{4} \mathrm{C}+\mathrm{Na}_{2} \mathrm{~B}_{4} \mathrm{O}_{7} \rightarrow 28 \mathrm{~B}+\mathrm{Na}_{2} \mathrm{O}+6 \mathrm{CO}$ & $+1442 \cdots(22)$ \\
\hline $\mathrm{Ti}+\mathrm{O}_{2} \rightarrow \mathrm{TiO}_{2}$ & $-739 \cdots(23)$ \\
\hline $\mathrm{Ti}+1 / 2 \mathrm{O}_{2} \rightarrow \mathrm{TiO}$ & $-431 \quad \cdots(24)$ \\
\hline
\end{tabular}

表 1 よりTiホウ化物と共にTi酸化物が認められた。 $\Delta G$ の比較では(15)〜(21式よりも(23)，(24)式の反応が優先す ると考える。しかしTiホウ化物が優先的に生成した理 由は $\mathrm{B}_{4} \mathrm{C}, \mathrm{NH}_{4} \mathrm{Cl}$ 等の分解生成物 $\mathrm{CO}, \mathrm{H}_{2}, \mathrm{~N}_{2}$ 等が試 料表面を覆い, 試料表面の $\mathrm{O}_{2}$ 濃度が低下したためと考 えられる。

\section{3 Tiホウ化物生成に及ぼす粉末中ペーストホゥ 化と大気中ペーストホウ化との比較}

図 1 は薬剤を被覆したTiとTi合金を粉末 $\left(2 \% \mathrm{~B}_{4} \mathrm{C}\right.$ 含

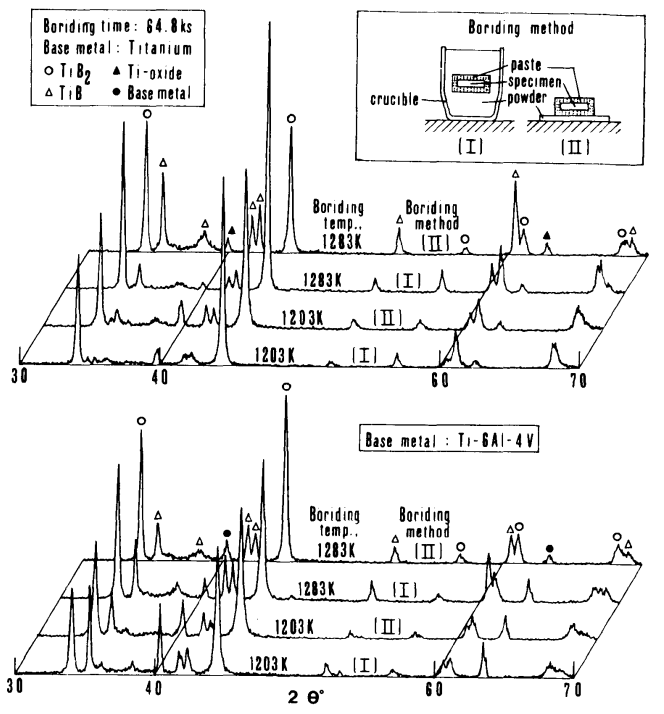

Fig. 1 Comparison between paste-boriding submerged in $\mathrm{Al}_{2} \mathrm{O}_{3}$ powder with $\mathrm{B}_{4} \mathrm{C}(\mathrm{I})$ and paste-boriding in air (II ) on x-ray diffraction patterns observed from specimen surface.

有 $\mathrm{Al}_{2} \mathrm{O}_{3}$ ) 中ペーストホゥ化( I ), 及び大気中ペースト ホウ化（II）した場合の試料表面のX線回折結果である。 処理温度は $1203 \mathrm{~K}$ と $1283 \mathrm{~K}$ で処理時間は各々 $64.8 \mathrm{ks}$ であ る。本法によるTiとTi合金の処理では検出されたピー クはTiB ${ }_{2}$ が主であり，I，II方法ともにホゥ化物が生

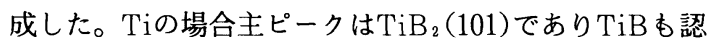
められる。またわずかに酸化物も認められた。IとIの 比較では1203K及び1283KともにTiB 2 (101) ピーク強度 は I の方が II りも大きい。この理由は I では高温にお いて試料に被覆した薬凪に接する粉末の部分が薬剤中の $\mathrm{B}_{4} \mathrm{C}$ 等により固化したことより, 外部からの $\mathrm{O}_{2}$ の侵入 を抑制した，すなわちホウ化が有効に行われたためと推 察される。このことは薬剤にき裂が生じた試料ではホウ 化物より酸化物が主に生成したことより理解できる。一 方Ti合金では, ホゥ化物生成に及ぼす I と II の方法の 違いは明確には認められない。この理由は前述したよう に高温において表面に安定な $\mathrm{Al}_{2} \mathrm{O}_{3}$ が生成するため母材 と薬剤あるいは $\mathrm{O}_{2}$ との反応性がTiに比べ劣ることが考 えられる。これは処理後の試料表面がTiよりあ平滑で あったこと, 生成したホゥ化物厚さが薄かったことから あ推察される。すなわちTi合金では簡単なII の方法で あTiホウ化物が得られることが明らかとなった。

\section{3. $4 \mathrm{Ti}$ ホウ化物皮膜の厚さ，X線回折及び断面組織}

図 2 はTi及びTi合金を種々の温度, 時間で粉末中ペストホゥ化した場合のホウ化物皮膜の平均厚さ（ $\mathrm{TiB}_{2}$ +TiB）である。形成した皮膜厚さは数 $\mu \mathrm{m}$ のばらつき があるが平均値は図のように処理時間に対しておおよそ 放物線則にしたがって増加した。Ti合金の場合, $1203 \mathrm{~K}$ 


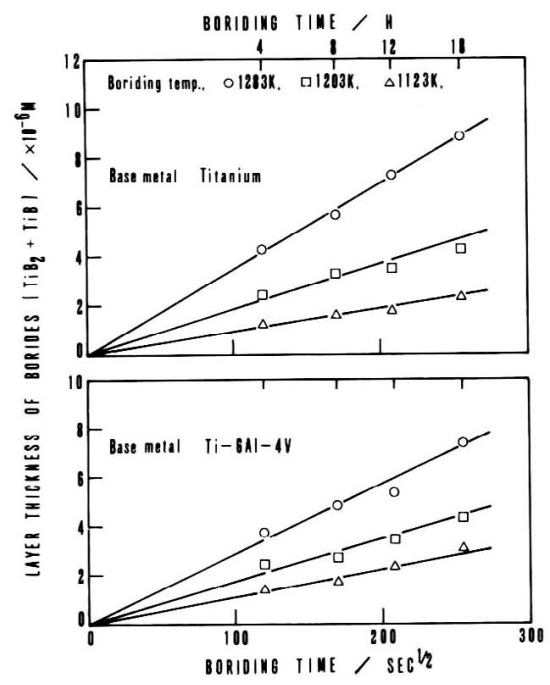

Fig. 2 Average thickness of titanium boride layers $\left(\mathrm{TiB}_{2}+\right.$ $\mathrm{TiB}$ ) formed on titanium and Ti- $6 \mathrm{Al}-4 \mathrm{~V}$ alloy by paste-boriding.

で28.8ksの処理では約 $2.7 \mu \mathrm{m}$ 厚さのホウ化物が得られ た。TiはTi合金に比べ同一処理条件ではわずかに厚い 皮膜が得られ，ホウ化物が生成しやすいと言える。この 理由は前述したようにTi合金は表面に生成した $\mathrm{Al}_{2} \mathrm{O}_{3}$ がBの内部への拡散を抑制しているためと考えられる。 1123KではTi合金の方が皮膜厚さがわずかに厚いが，こ れは皮膜が極めて薄く明確な差とは断定できない。図 3 はペーストホウ化したTiとTi合金の種々の深さから観 察されたX線回折図である。Tiの場合表面は $\mathrm{TiB}_{2}$ が主 であり，わずかにTiBも認められる。表面をわずかに研 磨すると $\mathrm{TiB}_{2}$ 強度が低下し, $\mathrm{TiB}$ 素地加らの強度が 増加した。さらに研磨するとTiB及びTiB 2 (101) とす に低下し，素地強度加增加する。Ti合金についてあ Ti の場合と同様であった。すなわちぺーストホウ化により 生成したホゥ化物は $\mathrm{TiB}_{2}$ と $\mathrm{TiB} の ~ 2$ 相であり, 最表面 に $\mathrm{TiB}_{2}$, 内側にTiBが存在する。最表面で 2 相が認め られるのは $\mathrm{TiB}_{2}$ 相が薄いためであろう。またTi合金で は最表面でもわずかに素地が検出された。

本研究では $1283 \mathrm{~K} て ゙ 64.8 \mathrm{ks}$ ，ペーストホウ化したTi表 面に生成した $\mathrm{TiB}_{2}$ 結晶の格子定数は $\mathrm{a}=3.029 \AA, \mathrm{c}=$ $3.231 \AA ⿻ \mathrm{c} / \mathrm{a}=1.067$ であった。この值はJCPDS值（No 35-0741）及び測定した市販 $\mathrm{TiB}_{2}$ 粉 $(4.2 \mu \mathrm{m}$ 径) のそ れらと類似の値を示した。図 4 は1123，1203，1283Kの 各温度で各々 $14.4 及 ひ ゙ 64.8 \mathrm{ks}$, ペーストホゥ化したTi合 金及びTiの断面組織である。Ti合金では $\alpha / \beta$ 変態点以 下の1123Kで14.4ksの処理であホウ化物生成が認められ た。そして表面は1283Kの高温度処理でも平滑であり， 処理に起因する表面部のはく離は認められない。一方, $\mathrm{Ti}$ の場合はTi合金に比べ表面の粗れが激しく，特に 1283Kの処理では著しい。また処理や研磨による表面部

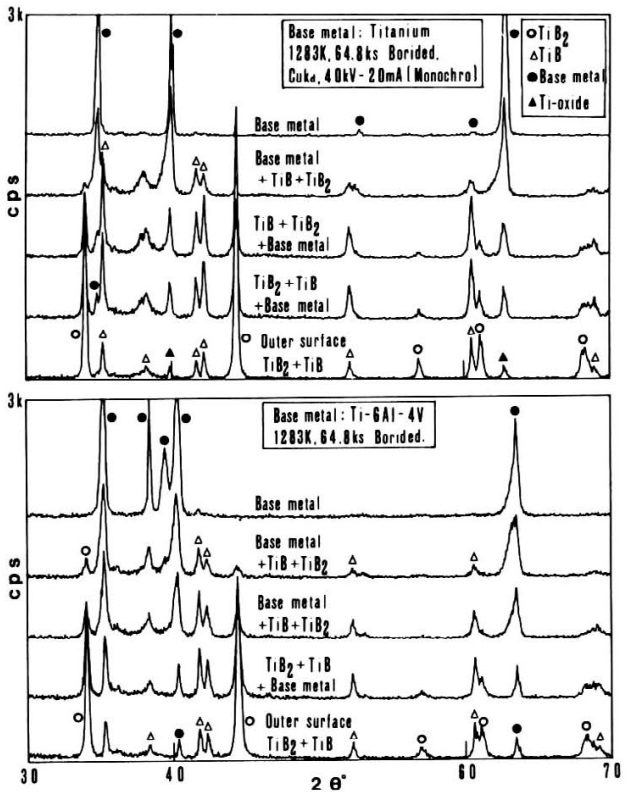

Fig. 3 X-ray diffraction patterns observed from surfaces in various depth of titanium and Ti-6Al-4V alloy borided at $1283 \mathrm{~K}$ for $64.8 \mathrm{ks}$.

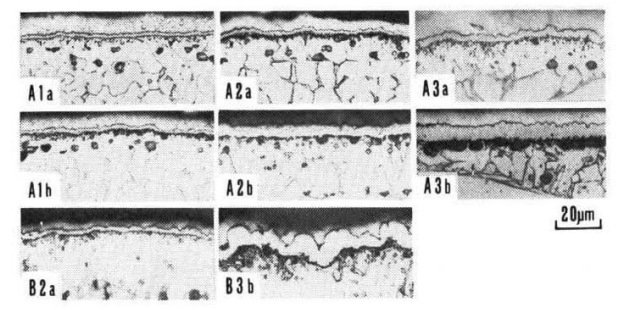

Fig. 4 Cress-sectional microstructures of Ti-6Al-4V alloy and titanium borided at various temperatures and times. A : Ti-6Al-4V, B : Ti, Boriding temp. ; 1 : $1123 \mathrm{~K}, 2: 1203 \mathrm{~K}, 3: 1283 \mathrm{~K}$, Boriding time ; a : 14.4 $\mathrm{ks}, \mathrm{b}: 64.4 \mathrm{ks}$.

のはく離が，表面より 40～50 $\mu \mathrm{m}$ 内部の結晶粒界で生じ やすい傾向が認められた。しかしホウ化物/素地の界面 ではそれはほとんど認められない。生成したホウ化物の 断面観察からあTi合金の方がTiよりあホウ化材料とし て優れていると言える。

\section{3. $5 \mathrm{Ti}$ ホウ化物皮膜の硬さ及ひ耐摩耗性}

図 5 は1283Kで64.8ks，ペーストホウ化したTi及び Ti合金断面の硬さ分布である。試料を約15度傾斜させ 鏡面研磨して測定した。Ti及びTi合金ともにホゥ化物 の表面硬さは $\mathrm{H}_{\mathrm{K}} 3200 \sim 4500$ であり, 鉄ホゥ化物 ${ }^{16}$ に比 べ著しく硬い值であった。また表面汃ら内部に確さ勾配

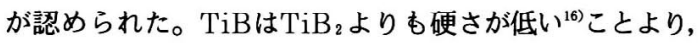
生成したホウ化物は表面が $\mathrm{TiB}_{2}$, 内部がTiBであると 言える。硬さ值にばらつきがあるが，これは極めて硬い ために圧痕の測定誤差が主原因であろう。素地部の硬さ はTiの場合ホウ化物直下から内部へ硬さ勾配が認めら 


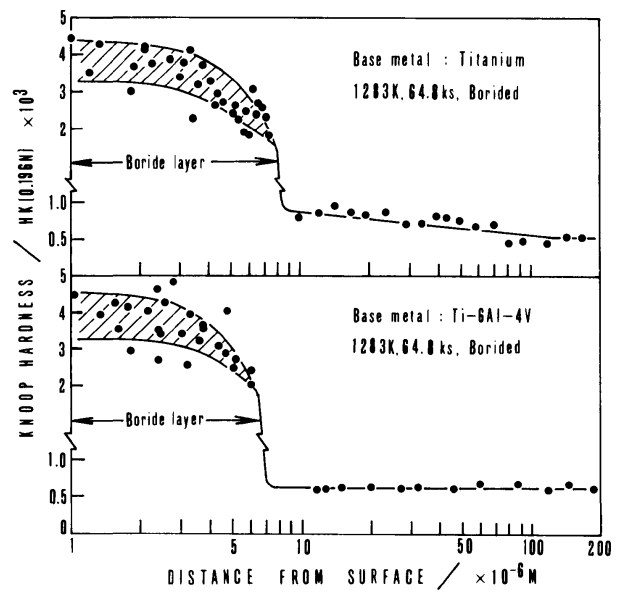

Fig. 5 Microhardness change of cross-section of boried titanium and Ti- $6 \mathrm{Al}-4 \mathrm{~V}$ alloy.

れたがTi合金では一定であった。TiはN, O, C等の不純 物が混入すると硬さは增す的，と言われ，Bについてあ 同様なことが予想されるが明確ではなく，今後の検討課 題である。

表 2 はTi及びTi合金の耐摩耗性に及ぼすぺーストホ ウ化の影響である。とあにホウ化することにより摩耗減 量は著しく減少した。また摩擦係数も未処理材に比べ半 分以下である。すなわち Ti及びTi合金にぺーストホウ 化することにより耐摩耗性は著しく向上することが明ら かとなった。一部のホウ化材で試験後重量がわずかに增 加したが，これは試料表面のわずかな凹凸に相手材が転 移したためと思われる。pin摩擦面はマク口的には試験 前とほとんど変化がなく, disk上の摩耗痕も極めて少 ない。一方末処理材では金属粉が生成して，摩耗面状態 より摩耗機構を分類すると輝面摩耗であった。試験中の 摩擦トルクの変動はホウ化材の場合は, 極めて少なく安 定した摩擦だが，未処理材では激しい。これは相手材と の凝着や摩耗粉の相手材への転移あるいは再転移が生じ て, 試験片に衝撃的な負荷が連続してかかったためと考 えられる。

\section{4. 結言}

$\mathrm{B}_{4} \mathrm{C}$ と $\mathrm{Na}_{2} \mathrm{~B}_{4} \mathrm{O}_{7}$ を主成分, $\mathrm{NaBF}_{4}, \mathrm{NH}_{4} \mathrm{Cl}, \mathrm{NaCl}$

Table 2 Influence of paste-boriding on wear resistance of titanium and Ti- $6 \mathrm{Al}-4 \mathrm{~V}$ alloy.

\begin{tabular}{l|c|c|c}
\hline \multicolumn{1}{c|}{ specimen } & Load $(\boldsymbol{N})$ & Wear loss $(\mathrm{mg})$ & $\mu$ \\
\hline Borided Ii & 64.7 & 0.6 & 0.19 \\
& 171.6 & +0.6 & 0.17 \\
\hline Borided Ti6Al4V & 64.7 & +0.3 & 0.20 \\
& 171.6 & +0.2 & 0.19 \\
\hline Unborided Ti & 64.7 & $53^{\star}$ & 0.49 \\
Unborided Ti6Al4V & 64.7 & $21^{\star}$ & 0.47 \\
\hline
\end{tabular}

Pin-on-disk type test, $\mu$ : Coefficient of friction, Wear time: $3.6 \mathrm{ks}$ or $0.3 \mathrm{ks}$, Lubricant: Turbine oil, $323 \mathrm{~K}, 50 \mathrm{~mL} / \mathrm{min}$. Disk: $\$ 45 \mathrm{C}$ (HRC51), Revolution: $100 \mathrm{rpm}$, Boriding specimenes were borided at $1283 \mathrm{~K}$ for $64.8 \mathrm{ks}$.
ホウ化促進剤, $\mathrm{Ca}(\mathrm{OH})_{2}$ を粘結剤として，これらの混 合物をエチルアルコールでペースト状にしてTiとTi- 6 Al- 4 V 合金に塗布し，大気中加熱することにより表面 にTiホウ化物を生成させることができた。薬剤の最適 配合比はTiでは $65 \mathrm{wt} \% \mathrm{~B}_{4} \mathrm{C}, 20 \mathrm{wt} \% \mathrm{Na}_{2} \mathrm{~B}_{4} \mathrm{O}_{7}, 8.5$ wt $\% \mathrm{NaBF}_{4}, \quad 2.5 \mathrm{wt} \%\left(\mathrm{NH}_{4} \mathrm{Cl}+\mathrm{NaCl}\right), \quad 4.0 \mathrm{wt} \%$ $\mathrm{Ca}(\mathrm{OH})_{2}$ であり, Ti- $6 \mathrm{Al}-4 \mathrm{~V}$ 合金では $75 \mathrm{wt} \% \mathrm{~B}_{4} \mathrm{C}$, $10 \mathrm{wt} \% \mathrm{Na}_{2} \mathrm{~B}_{4} \mathrm{O}_{7}$, 他はTiの場合と同様であった。生成 したTiホウ化物は表面側に $\mathrm{TiB}_{2}$, 内部にTiBの 2 相で あり，その表面硬さは $\mathrm{H}_{\kappa}(0.196 \mathrm{~N}) 3200 〜 4500$ でっ た。また表面から内部に入るにしたがい, ホゥ化物に硬 さ勾配が認められた。Tiでは粉末中ペーストホゥ化 $\left(\mathrm{Al}_{2} \mathrm{O}_{3}\right.$ が主成分）の方が大気中ペーストホゥ化よりあ ホウ化物が生成しやすい。しかしTi- $6 \mathrm{Al}-4 \mathrm{~V}$ 合金では 両者に明確な差は認められない。生成したホウ化物皮膜 の平均厚さは同一処理条件ではTiの方がTi- $6 \mathrm{Al}-4 \mathrm{~V}$ 合金よりあわずかに厚い。 $\mathrm{Ti}$ 表面に生成した $\mathrm{TiB}_{2}$ 結晶

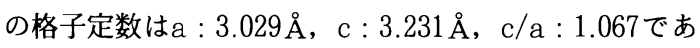
り, JCPDS值と類似していた。ホウ化処理材料として はTi- 6 Al- 4 V合金の方がTiよりも処理後の表面粗さ の観点より優れている。Ti及びTi- 6 Al- 4 V合金にペー ストホウ化することにより耐摩耗性は著しく向上する。

(1989-8-9 受理)

\section{文献}

1) H. Kunst ; J. Less Common Met., 43, 307 (1975)

2) R. Chatterjee-Fischer, O. Schaaber ; " Heat-treatment 76 ", p.27 (1976)

3) M. Kornmann, R. Funk ; Aluminium, 53, 249 (1977)

4 ）塚越庸弘, 当摩照夫, 木村政美 ; 日本音響学会誌, 36,343 (1980)

5 ）中野 理，笹野久興，鈴木敏之; 日本熱処理技術協会第13 回講演大会予稿集, p.17 (1981)

6 ) S. C. Singhal ; Thin Solid Films, 53, 375 (1978)

7 ）斎藤 茂, 井筒 昇, 米田 登; 金属表面技術協会第51回 講演大会講演要旨集, p.132（1975）

8 ）河上 護, 百瀬 治, 梶山佳孝; 金属表面技術， 38，540 (1987)

9 ) 田村久義, 平井敏洋, 木村啓造 ; 日本熱処理技術協会第18 回講演大会予稿集, p.64 (1984)

10) H. Pierson, E. Randich ; Thin Solid Films, 54, 119 (1978)

11) O. Kubaschewski, C. B. Alcock ; Metallurgical Thermochemistry, 5 th ed, p.19 (Pergamon, 1979)

12) O. Kubaschewski, C. B. Alcock ; Metallurgical Thermochemistry, 5 th ed, p.267 (Pergamon, 1979)

13) JANAF Thermochemical Tables (NBS, Washington, DC. 3 th ed, June 1985)

14）横川晴美 ; 化学技術研究所報告, 83，27（1988）

15）小松 登, 大林幹男, 遠藤淳二; 日本金属学会誌, 38,481 (1974)

16）ヴェ・ペ・グルホフ；鉄と鋼のボロナイジング（日ソ通信 社, 1970)

17）米田 登, 小浦延幸, 本田晴彦 ; 金属表面技術, 24, 517 (1973)

18）細川一夫 ; 日本金属学会誌，40，57（1976）

19）木村啓造 ; 軽金属, 18, 347 （1968） 